Old Dominion University

ODU Digital Commons

History Faculty Publications

History

2005

What Is Your Anthropology? What Are Your Ethics?

Robert H. Holden

Old Dominion University, rholden@odu.edu

Follow this and additional works at: https://digitalcommons.odu.edu/history_fac_pubs

Part of the Intellectual History Commons

Original Publication Citation

Holden, R. H. (2005). What is your anthropology? What are your ethics? Historically Speaking, 6(4), 35-37. https://doi.org/10.1353/hsp.2005.0001

This Article is brought to you for free and open access by the History at ODU Digital Commons. It has been accepted for inclusion in History Faculty Publications by an authorized administrator of ODU Digital Commons. For more information, please contact digitalcommons@odu.edu. 


\title{
What Is Your Anthropology? What Are Your Ethics?
}

\author{
Robert H. Holden
}

$\mathbf{W}$ e tend to think of the great ridge that rose up inside the historical profession some three decades ago, splitting historians into two camps, as some kind of epistemological event. Ancient disagreements about the nature (and existence) of truth suddenly became more extreme and divisive. Now, the biggest flags wave over the "relativists" on one side, and the "truth seekers" on the other. Smaller banners ("moderate historicists," "constructivists," "positivists," etc.) fly here and there along the slopes of lower-lying ranges on each side of the great divide, itself breached by passes and tunnels excavated by historians loathe to commit themselves to either camp.

But there is another way of looking at what divides historians. Who we think we are affects what we think we can know: "We are encouraged these days," Thomas Nagel has pointed out, "to think of ourselves as contingent organisms arbitrarily thrown up by evolution. There is no reason in advance to expect a finite creature like that to be able to do more than accumulate information at the perceptual and conceptual level it occupies by nature."1

I argue (from the standpoint of philosophical realism) that disagreements rooted in different epistemological assumptions might also be understood as rival ways of answering the question, "Who is the human person?" I find it curious that even as we cram our journals with articles about "identity," we don't seem to acknowledge the deeper differences over how we define the most fundamental of all identities. I argue, furthermore, that these differences in philosophical anthropology have ethical consequences for the writing of history: different anthropologies lead to fundamentally different ethics of knowledge. And those ethics come into play whenever historians choose topics to investigate, apply methods of research, and propose interpretations.

First, to the anthropological question. Of all the branches of philosophy, Henri-Irénée Marrou argued, historical knowledge depends most on that dealing with anthropology. He likened the historian's chosen philosophy of man to an axle or a nervous system, so that what we write as historians "stands or falls" with our philosophical anthropology, our idea of the human person. ${ }^{2}$ Most historians agree that we need to take into account both the spontaneity and creativity of the individual person as well as the limits and conditions that restrict individual freedom. So, just who is this free being who makes history, including the ideologies and institutions that condition his or her very freedom?

One reason that the question has excited so little interest among historians may be the extreme historicism that prevails today. Of what use is a theory of the person when one assumes that all of man's works and his very identity are nothing but expressions of history itself, and therefore merely relative to some time and place? ${ }^{3}$ What passed for philosophical anthropology in the 20th century ended up being the reductio ad absurdum of Rousseau's idea of man as malleable, bereft of any fixed nature. "Man is what has happened to him, what he has done," said José Ortega y Gasset, theorist of historicism. "This is why it makes no sense to put limits on what man is capable of being." Man has no nature, the Spanish philosopher declared; he only has a history. ${ }^{4}$

It is, I submit, this particularly miserable idea of the human person-namely, the belief that our nature is nothing but our historicity-that ultimately accounts for the vague sensation among some of us that in reading a good deal of history today we are drinking from a poisoned well. What's wrong with the water is not so much the relativistic assumptions about knowledge and truth but its Rousseauian naturalism. The water is not potable because it is not compatible with whom we know ourselves to be.

Why should historians be guided by a belief in man's essential nature? Because without it, anything man does, as well as anything he has done, is as valuable or as valueless as anything else. History would be meaningless. Sitting down to write a constitution, hauling coal out of the ground, or nursing a baby would be substantially equivalent to, say, clobbering your brother to death with a blunt instrument. Or, as one philosopher commented at a public forum a couple of weeks after September 11, 2001, since there was no such thing as evil, the Twin Towers catastrophe really had no special meaning at all. It was, he declared, "just another plane crash."

Unlike most historians, Thomas Klubock has helpfully called specific attention to his belief in Rousseauian naturalism. The need for more studies of "homosocial networks and ties" is obstructed by "an implicit assumption of naturalized heterosexuality, of an inevitable male-female binary opposition."s Similarly, Steven C. Topik proposed a vast research program to answer the question, "does coffee production impose certain structures and world views?" His hypothesis that a wide range of beliefs, actions, and attitudes might be determined by the simple fact of living in a coffee-growing region of the world was grounded in what he approvingly called a "central observation" of Karl Marx: that man only "'begins to distinguish himself from the animal the moment he begins to produce his means of subsistence, a step required by his physical organization .... What they [individuals] are, therefore, coincides with what they produce and how they produce. The nature of individuals thus depends on the material conditions which determine their production."'6 It is hard to believe that Topik really thinks that what he himself is "coincides" with the books and articles that he has written and how he has written them, or that he thinks that, in thus producing his own "means of subsistence," he unveils the only difference between Steve Topik and, say, a grasshopper or a grizzly bear.

The anthropologist Sidney Mintz's Worker in the Cane: A Puerto Rican Life History, first published in 1960, is still in print and remains a model for a new kind of history, according to the historian Florencia Mallon. The book is the product of hundreds of hours of conversations between Mintz and Eustaquio (Taso) Zayas Alvarado, a Puerto Rican cane cutter and father of ten children. Evidently, Taso attracted Mintz's interest because of his participation in union and left-wing political causes and his intelligence and above-average leadership abilities. But not long after Mintz undertook the interviews, Taso converted from a non-practicing Catholic to the 
Pentecostal Church of God, withdrawing from union and political causes. Astounded and disappointed, Mintz realized that his proletarian hero had feet of clay.

In the course of thirteen pages in the last part of the book, Mintz desperately sorts through a series of social, economic, ideological, and psychological explanations for Taso's conversion before settling on the possibility that "conversion to a revivalist sect may be viewed as a way of increasing one's social and economic mobility." Or maybe Taso was just overcome by guilt feelings of some kind. Mintz invited the reader to share his own chilling conclusion: to see in Taso's life "the waste I think I see: the waste of a mind that stands above the others." Taso, the reader is left to infer, is nothing more than an animal who reasons, and whether he reasons well or badly, according to Mintz's precepts, is the only thing that interests the researcher. There is no place here for a spiritual dimension to which politics and class struggle might rightly be subordinated.

Historians may have rejected the existence of a human nature. But they have, strangely enough, embraced with enthusiasm Marx's Eleventh Thesis on Feuerbach: "The philosophers have only interpreted the world, in various ways; the point, however, is to change it."8 The application of Marx's thesis depends on the absence of any coherent philosophical anthropology, which would pose an intolerable restriction on the freedom of historians to advance their favorite political projects.

But what accounts for this compulsion to see and judge everything in terms of some emancipatory political project? "In the absence of religious belief," Anthony Daniels suggests, the compulsion "answers man's need for a purpose that transcends the humdrum tasks and flux of day-to-day existence in a settled democratic society. In doing so, it reassures the individual of his personal significance even as he frets about his insignificance." As the border between personal life and the political realm breaks down, other limits seem to melt away. The compulsion intensifies, "even as some of its ostensible ends are met." Perhaps this is what accounts for the rapture with which so many historians and other scholars gaze upon the life of the late Michel Foucault. Here was a brave intellectual, they say, who tried to live as if he didn't really believe there was any moral difference between the assassin and the victim. To live in that way no doubt does takes a certain amount of courage. Foucault lived and died according to the Eleventh Thesis on Feuerbach even as he declared the death of the very idea of a philosophical anthropology. "To die for the love of boys," Foucault sighed the year before his death of AIDS in 1984. "What could be more beautiful?"10 But what about "the boys?" They were sheer historicity, which is to say, nothing.

The problem is an ethical one, but it is first of all anthropological. To speak of "moral rules and principles," according to the philosopher John Rist, "without reference to the nature of man and of each man risks being if not literal nonsense, at least abstract, useless, even dangerous fantasy-such as that of abstract liberalism." Every ethical enunciation invariably assumes some "theory about the kind of beings who can contemplate," whatever ethical goal is proposed. This means that every ethical theory is also a natural law theory, and that the best moral theories will therefore be linked to some "truer, more defensible accounts of human nature." 11

I would argue, therefore, that the great ridge that divides historians is best conceived as one that separates us according to radically different theories of the person. The dominant one reduces man to a material expression of the natural world, not essentially different from an animal. A much longer and more humane tradition began with Aristotle, flourished under the influence of St. Augustine and St. Thomas Aquinas, and ripened in the 20th century with the development of the philosophy of personalism. 12 This tradition yields accounts of the past shaped by the conviction that the human person, as an embodied spirit created to fulfill a specific vocation in life, is more than a self-made "identity" or "producer," that there are aspects of human nature that are unchangeable, and that to flout them is to invite disaster. Historians who approach the past with these premises may well tackle the same topics as their colleagues on the other side of the ridge, but they pose different kinds of questions and offer interpretations of another order.

Of course, historians rarely announce their philosophical anthropologies. Detecting them may be difficult or impossible. But that doesn't mean they are irrelevant. Without referring directly to either anthropology or personalism, the historian François Xavier Guerra showed just how powerfully influential a personalist-oriented philosophy can be in the writing of history. Arguing against the tendency of so many historians to attribute pri- mary causal authority to abstract economic, social, demographic, and mental "structures" and "forces," Guerra asked: "What are these structures but a formalization of relations between men and nature, or between men and other men?" The ultimate subject of every historical inquiry is the human person, acting as an individual or as a member of a group. To assume, as we often do, that individual persons merely represent or incarnate some nation, people, or social group ("the peasantry," "the landless," etc.) is a grave methodological error. ${ }^{13}$

One of the most striking consequence of these distinctive anthropologies lies in their corresponding ethics of knowledge. The Rousseauian anthropology yields a utilitarian ethics. The Aristotelian anthropology's assumption of an essential human nature links it naturally with a virtue-based ethics; having certain virtues makes possible the attainment of the telos imposed by human nature. In the first paragraph of his classic introduction to historiography, Marrou asked, "What is the correct behavior of reason in the field of history?" What were "the virtues of the historian"? Here, ethics is not about codes of professional conduct or rules against plagiarism. There is a deeper ethic at play-an ethics of knowledge or a normative epistemology - that governs the selection of topics, the purpose of research, the choice of hypotheses and interpretations.

Essays devoted to ethical self-reflection of a rather different order have multiplied in the academy during the last decade or so. "The mission of the African-American scholar," Peter J. Paris of Princeton University declared in his 1995 inaugural address as president of the American Academy of Religion, "is a moral mission, because its final aim is the realization of racial justice in the nation's thought and practice." The main purpose of feminist research, according to Gesa E. Kirsch, is to "empower [women] to change the conditions of their lives." To Clifford Christians, a "basic norm" of what has come to be called "interpretive research" is that of "enabling the humane transformation of the multiple spheres of community life-religion, politics, ethnicity, gender, and so forth." I4 For the Yale historian Emilia Viotti da Costa, historians ought to be opening up "new roads to a more open and truly democratic world, where all people of different genders, classes, ethnicities, religions, and nationalities will come together to participate equally in the wealth of the world."15 
These pronouncements represent utilitarian ethics at its crudest. The past is a databank to be pillaged for the advancement of one or another social change project. The underlying anthropology seems to be that of the naturalist conception of the human person as nothing more than a complex animal thrown up by evolution. On this view, there can be no logical rejoinder to the manipulation or distortion of the past in the service of ideology. None of the scholars just quoted hints at a theory of the person. To have done so might have sunk them in a morass of contradiction - between their utopian goals and reality, between the evident necessity to know the truth even when the truth fails to point to utopia. Nor do any of them propose any objective grounding for the moral purposes that they think should guide research. Precisely why should I orient my work toward the "humane transformation of the multiple spheres," etc.?

On the other hand, since the 1980 s epistemologists and ethicists have been investigating the special way in which virtue ethics applies to the production of knowledge. "The fundamental questions of epistemology," wrote Linda Zagzebski, "are varieties of the question 'How ought we to go about finding out the truth?' or 'What counts as a good belief?' or 'What gives us understanding?" The goodness of knowledge, she argued, "is partially constituted by the motive to get it." What Aristotelians and Thomists call "the intellectual virtues" are nothing but forms of moral virtues, which is why "epistemic evaluation is a form of moral evaluation."16 Similarly, Gilbert Meilaender, citing Augustine, Aquinas, and John Henry Newman, argued that knowledge which is not acquired in accord with what we know to be good is illicit. Knowledge is not something that one picks up in a supposedly autonomous intellectual sphere; its acquisition depends on prior knowledge of what is good and on the proper motivation. ${ }^{17}$

Perhaps this is what Octavio Paz had in mind when, four years before his death in 1998, he wrote, "The exercise of criticism demands intelligence and likewise character, moral rigor." Denouncing "evil,", "lies," "the nihilism of relativity," and the "ideological intoxication" of so many Latin American intellectuals, Paz exalted the virtues and even proposed a recovery of religious tradition.18 Though Paz is not known to have been a believer, his words make him an intellectual companion of the great French Thomist, A. D Sertillanges, who long ago reminded would-be scholars that "the purity of thought presupposes purity of the soul."19

Perhaps it is time for historians to begin asking each other, and their students, "What's your anthropology? What's your ethics?"

\section{Robert H. Holden is associate professor of Latin American history at Old Dominion University. His most recent book is Armies Without Nations: Public Violence and State Formation in Central America, 1821-1961 (Oxford University Press, 2004).}

1 Thomas Nagel, The View from Nowhere (Oxford University Press, 1986), 70.

2 Henri-Irẻnée Marrou, El conocimiento histórico (Idea Books, 1999) tr. De la connaissance historique (Éditions du Seuil, 1954), 127.

${ }^{3}$ Ignacio Olábarri's discovery that historicism has poisoned every school of history over the last two hundred years, and his concern for the absence of a "common historiographical tradition," inspired his call for the restoration of a "unitary conception of humanity through philosophical anthropology," the core discipline of scholarship; "New" New History: A Longue Duree Structure," History and Theory 34 (1995): 27. Elsewhere Olábarri observed that the historicists effectively replaced philosophical anthropology with history; "En torno al objeto y carácter de la ciencia histórica," Anuario filosófico 17 (1984):163.

4 José Ortega y Gasset, Historia como sistema, 2nd ed. (Revista de Occidente, 1942), 63.

5 Thomas Klubock, "Writing the History of Women and Gender in Twentieth-Century Chile," Hispanic American Historical Review 81 (2001): 516.

${ }^{6}$ Steven C. Topik, "Coffee Anyone? Recent Research on Latin American Coffee Societies," Hispanic American Historical Review 80 (May 2000): 226, 228; the quotation is from Marx's The German Ideology.

7 Sidney Mintz, Worker in the Cane: A Puerto Rican Life History (Yale University Press, 1960), 257-270, 277, 1, 11. Mallon thought that the disappointment Mintz expressed over Taso's conversion was a particularly welcome example of the "dialogic" approach historians should take toward the objects of their research: "Bearing Witness in Hard Times: Ethnography and Testimonio in a Postrevolutionary Age," in G. M. Joseph, ed., Reclaiming the Political in Latin American History: Essays from the North (Duke University Press, 2001), 311-18.

${ }^{8}$ Karl Marx, "Theses on Feuerbach," in Robert C. Tucker, ed., The Marx-Engels Reader (W. W. Norton \& Co., 1978), 145.
${ }^{9}$ Anthony Daniels, "Up from Communism," The New Criterion 21 (2003): 34-35.

10 James Miller, The Passion of Michel Foucault (Harvard University Press, 1993), 350.

11 John Rist, Real Ethics: Rethinking the Foundations of Morality (Cambridge University Press, 2001), 138, 61-62.

12 By "personalism" I mean that variety which emerged between the wars in Europe, where it flourished under French Catholic auspices through the work of Jacques Maritain, Emmanuel Mounier, and Maurice Nédoncelle, strongly influencing the thinking of the Polish philosopher Karol Wojytla, who was elected Pope John Paul II. For an introduction, see Juan Manuel Burgos, El personalismo (Ediciones Palabra, 2000); for the same author's attempt to synthesize a personalist anthropology, see his Antropologia: una guia para la existencia (Ediciones Palabra, 2003).

${ }^{13}$ François Xavier Guerra, "El renacer de la historia política: razones y propuestas," in José Andrés-Gallego, ed., New History, Nouvelle Histoire: Hacia una Nueva Historia (Actas, 1993), 221-245.

14 Peter J. Paris, "The Ethics of African American Religious Scholarship," Journal of the American Academy of Religion 64 (1996): 489; Gesa E. Kirsch, Ethical Dilemmas in Feminist Research: The Politics of Location, Interpretation, and Publication (State University of New York Press, 1999), 2-3; and Clifford G. Christians, "Ethics and Politics in Qualitative Research," in Norman K. Denzin and Yvonna S. Lincoln, eds., Handbook of Qualitative Research (Sage Publications, 2000), 147-48.

15 Emilia Viotti da Costa, "New Publics, New Politics, New Histories: From Economic Reductionism to Cultural Reductionism-in Search of Dialectics," in Joseph, ed., Reclaiming the Political in Latin American History, 29.

${ }^{16}$ Linda Zagzebski, Virtues of the Mind: An Inquiry into the Nature of Virtue and the Ethical Foundations of Knowledge (Cambridge University Press, 1996), 334-39, xiv-xv, 6, 27071,273 . Also see the essays collected in Guy Axtell, ed., Knowledge, Belief, and Character: Readings in Virtue Epistemology (Rowman \& Littlefield, 2000) and Michael DePaul and Linda Zagzebski, eds., Intellectual Virtue: Perspectives from Ethics and Epistemology (Oxford University Press, 2003).

17 Gilbert Meilaender, The Theory and Practice of Virtue (University of Notre Dame Press, 1984), ch. 6 .

${ }^{18}$ Octavio Paz, Itinerary: An Intellectual Journey (Harcourt, 1999), 75-76, 78, 28, 89-90, 92-93, 9597.

${ }^{19}$ A.-D Sertillanges, La vida intelectual: $S u$ espiritu,sus condiciones, sus métodos (Ediciones Encuentro, 2003 [1920]), 28-30. 